\title{
Church and Space in the Middle Ages
}

On the publication of their two recent volumes in 2016, ${ }^{1}$ the Annales invited Dominique Iogna-Prat and Florian Mazel to participate in an exercise in lecture croisée. ${ }^{2}$ The aim was less to mark this publication than to present, on a more profound level, the new developments in our understanding of medieval societies to which these two authors have directly contributed. Indeed, the history of the Middle Ages, particularly in France, is currently the site of a thorough restructuring of the questions that link the study of the Church to an analysis of space. Since the early 1990s, we have seen the progressive development of historical interpretations that accord the Church a central place in the process of political and social construction during the High Middle Ages. The traditional division, whose historiographical influence was still so pronounced in the work of Georges Duby, ${ }^{3}$ separated the world of the clergy, restricted to "ecclesiastics," from that of the laity. This model has been replaced, however, by a new vision that places the Church, as an all-encompassing institution which sought to coalesce with the entire social body (and which Alain Guerreau termed, as early as 1980, Ecclesia ${ }^{4}$ ), at the heart of the history of medieval Europe. In this way, and in

1. Dominique Iogna-Prat, Cité de Dieu, cité des hommes. L'Église et l'architecture de la société, 1200-1500 (Paris: Presses universitaires de France, 2016); Florian Mazel, L'évêque et le territoire. L'invention médiévale de l'espace (Ve-XIII siècle) (Paris: Éd. du Seuil, 2016).

2. This dossier extends a discussion between the two authors on the same theme, organized by Patrick Boucheron as part of his seminar series at the Collège de France, on June 14, 2016: http://www.college-de-france.fr/site/patrick-boucheron/seminar-2016-06-14-17h00.htm.

3. Patrick Boucheron and Jacques Dalarun, eds., Georges Duby, portrait de l'historien en ses archives (Paris: Gallimard, 2015).

4. Alain Guerreau, Le féodalisme, un horizon théorique (Paris: Le Sycomore, 1980). 
close dialogue with international historiographical developments, the medieval Church has become the focal point for a new way of describing the mechanisms of social ordering among French historians. At the same time, ways of thinking about medieval space, themselves marked by a feudal history that forged a narrow link between spatial contexts and social analysis in regional monographs inspired by the French school of geography (from Duby to Pierre Toubert ${ }^{5}$ ), have also undergone a profound transformation within the broader framework of the "spatial turn" in the social sciences. They have been further transformed by a constructivist rereading of the history of space, a shift that has led Mazel to speak of "the medieval invention of space. ${ }^{6}$

The convergence of these two strands of research has led to the emergence of a new framework for understanding the history of medieval Europe, and the recent books by Iogna-Prat and Mazel not only illustrate this tendency but also mark a new stage in its development. Their revised periodisation of the Middle Ages points to the so-called Gregorian reform and the sociopolitical influence it exerted between the mid-eleventh and the mid-twelfth century as the major turning point in the social history of a Europe itself inscribed in a longue durée stretching from the end of the Roman Empire to the Enlightenment. This medieval society, whose material and spiritual architecture was drawn from the Church - in the broadest sense of the Christian community - progressively developed a new relationship with space that led to the emergence of territories linked to forms of individual and collective belonging. This dynamic was supported by the ecclesiastical institutions that ordered social life, such as churches (the subject of Iogna-Prat's previous book ${ }^{7}$ ), or the cemetery as studied by Michel Lawwers. ${ }^{8}$ Here we can observe a phenomenon of the "spatialization of the sacred," where sites controlled by the Church marked and hierarchized medieval space. This movement was followed by a "territorialization," first of dioceses and then of parishes, which no longer simply designated groups of believers but also expanses of space that were continuous and delimited. This double process contributed to the fixing of villages and the growth of urban centers, as well as to the construction of those territorialized political and administrative entities that determined a new form of sociospatial organization specific to Europe before the French Revolution.

In this new historiographical narrative that Iogna-Prat and Masel have helped to construct, the relationship between social morphology and spatial morphology is essential, and an important place is afforded to the sociology of Max Weber. Placed alongside one another, their two volumes show that this model and the periodiaation it implies urge a renewal of dialogue between historians of the Middle Ages and those of the early modern period. The evolution of social and spatial frameworks, and in particular the redeployment of ecclesiastical frameworks in the autonomous structuring of secular forms of social life and

5. Georges Duby, La société aux XI et XII siècles dans la région mâconnaise (Paris: Armand Colin, 1953); Pierre Toubert, Les structures du Latium médiéval. Le Latium méridional et la Sabine du IXe à la fin du XII siècle (Rome: École française de Rome, 1973).

6. Angelo Torre, "Un 'tournant spatial' en histoire? Paysages, regards, ressources," Annales HSS 63, no. 5 (2008): 1127-44.

7. Dominique Iogna-Prat, La maison Dieu. Une histoire monumentale de l'Église au Moyen Âge

(v. 800-v. 1200) (Paris: Éd du Seuil, 2006).
8. Michel Lauwers, Naissance du cimetière. L

médiéval (Paris: Aubier, 2005). 
of government-whether cities, principalities, or monarchic states-now lies at the heart of the debates that each of the authors draws on in their own way. The two have different methodological leanings which emphasize either the structuring of discourses or social practices; the nuances of their distinct approaches underscore either the role of polarization or that of territorialization, and insist on the primacy of either a vertical vision of the social organization of communities or on their horiwontal possibilities. Together, they show just how fertile this historiographical project can be. But-and this is why this exercise in lecture croisée is so very interesting - these distinctions do not obscure the shared movement toward a new interpretative model for understanding medieval societies and what they would become within a European modernity whose features must now also be redefined.

Les Annales 